\title{
Analisis Risiko Panen Tandan Buah Segar Kelapa Sawit di PT. Perkebunan Nusantara III Kebun Batang Toru Afdeling II Sipisang Tapanuli Selatan Sumatera Utara
}

\section{Risk Analysis of Harvesting of Palm Oil Fresh Fruit Bunches at PT. Perkebunan Nusantara III Batang Toru Afdeling II Garden Sipisang South Tapanuli North Sumatra}

\author{
Puja Satria, ${ }^{1)}$ Roni Afrizal, ${ }^{2)}$ Fedri Ibnusina ${ }^{3)}$ \\ ${ }^{1}$ Politeknik Pertanian Negeri Payakumbuh \\ ${ }^{2}$ Politeknik Pertanian Negeri Payakumbuh, rono_roso@gmail.com \\ ${ }^{3}$ Politeknik Pertanian Negeri Payakumbuh, is_fedri@ yahoo.com
}

\begin{abstract}
Abstrak
Kebun Batang Toru adalah salah satu Kebun PT. Perkebunan Nusantara III yang bergerak di bidang perkebunan karet dan kelapa sawit dengan produk tandan buah segar (TBS) dari kelapa sawit. Kebun Batang Toru menguasai hak kepemilikan 4.097,37 Ha yang terdiri dari 7 Afdeling (Karet dan Kelapa Sawit), salah satunya afdeling II Sipisang yang memiliki komoditas perkebunan kelapa sawit. Afdeling II Sipisang memiliki total luas 518,25 Ha, dengan luas lahan untuk komoditas kelapa sawit adalah 146 Ha. Kegiatan panen dan pasca panen dilakukan di PT. Perkebunan Nusantara III Batang Toru tanaman II afdeling Sipisang seperti pengurangan buah dan transportasi TBS ke titik pengumpulan. Tujuan dari penelitian ini adalah untuk menganalisis seberapa besar kehilangan hasil dan kemungkinan risiko insiden TBS kelapa sawit pasca panen. Jumlah kehilangan pascapanen TBS yang diperoleh adalah 7, 05\% dari total TBS yang dihasilkan. Kerugian terletak di tanah ke titik pengumpulan. Dampak kerugian pasca panen dari total TBS kelapa sawit adalah Rp 2.209.160,53 dengan probabilitas kejadian 4,4 persen.
\end{abstract}

Kata Kunci: minyak kelapa sawit, TBS, kehilangan pascapanen

\begin{abstract}
Batang Toru Garden is one of the Garden of PT. Perkebunan Nusantara III which is engaged in rubber plantation and oil palm plantation with fresh fruit bunches $(F F B)$ product from palm oil. Batang Toru gardens controlled the area of entitlement rights of 4,097.37 Ha consists of 7 Afdeling (Rubber and Palm Oil), one of which is afdeling II Sipisang which has a commodity of oil palm plantation. Afdeling II Sipisang has a total area of $518.25 \mathrm{Ha}$, with the land area for oil palm commodities is $146 \mathrm{Ha}$. Harvest and post harvest activities conducted at PT. Perkebunan Nusantara III Batang Toru plant II afdeling Sipisang such as fruit reduction and transport of FFB to the collection point. The purpose of this study is to analyze how much the loss of yield and the possibility of incident risk of post-harvest FFB of oil palm. The amount of lost postharvest of FFB obtained is 7, 05\% of the total total FFB generated. Losses are located on the land to the collection point. The impact of loss post-harvest loss of total palm oil FFB is Rp 2,209,160,53 with a probability incidence of 4.4 percent.
\end{abstract}

Keywords: palm oil, FFB, loss post-harvest 


\section{Pendahuluan}

Tanaman kelapa sawit (Elaeis Guineensis Jack.) berasal dari Nigeria, Afrika Barat. Sebagian pendapat yang lain justru menyatakan bahwa kelapa sawit berasal dari Amerika selatan yaitu Brazil. Hal ini karena lebih banyak ditemukan spesies kelapa sawit dihutan Brazil dibandingkan dengan di Afrika. Tanaman kelapa sawit hidup subur diluar daerah asalnya seperti, seperti Malaysia, Indonesia, Thailand, dan Papua Nugini. Produk utama tanaman kelapa sawit adalah tandan buahnya. Tandan buah ini akan diolah untuk menghasilkan minyak kelapa sawit (crude palm oill $\mathrm{CPO}$ ) dan minyak inti (palm karnel oill $\mathrm{PKO}$ ).

Pemanfaatan kelapa sawit paling banyak adalah untuk CPO dan PKO. CPO merupakan daging buah (mesocarp) yang dikeluarkan melalui perebusan dan pemerasan (pressan) yang dikenal sebagai minyak sawit kasar. Sedangkan PKO merupakan minyak yang berasal dari inti kelapa sawit yang dikenal sebagai minyak inti kelapa sawit [1]. PT. Perkebunan Nusantara III (Persero), disingkat PTPN III dibentuk berdasarkan PP No.8 Tahun 1996, Tanggal 14 Pebruari 1996 dalam rangkarestrukturisasi Badan Usaha Milik Negara (BUMN) dibidang perkebunan. PTPN III merupakan penggabungan kebun-kebun diwilayah Sumatera yang terdiri dari 34 Kebun, salah satunya adalah Kebun Batang Toru. Salah satu kerugian yang diterima dari pasca panen kelapa sawit adalah kehilangan hasil Tandan Buah Segar (TBS) dari setiap rantai yang dilalui sampai ke pengolahan akhir (loss post-harvest) [2]. Di bagian awal pemanenan, aktivitas pemanenan yang tidak sesuai dengan standar mengakibatkan kurang optimalnya hasil TBS yang diperoleh seperti brondolan yang terlepas maupun TBS mentah yang terpanen sehingga menimbulkan losses berupa pengurangan hasil produksi. Adapun tujuan dari penelitian ini adalah : 1) Menganalisis apa saja tahapan panen dan sumber-sumber yang mengakibatkan risiko panen TBS kelapa sawit di setiap rantai pasca panen yang dilalui hingga ke TPH di PT. Perkebunan Nusantara III Kebun Batang Toru Afdeling II Sipisang, Kabupaten Tapanuli Selatan, Sumatra Utara. 2) Menganalisis Berapa besar kehilangan hasil dan kemungkinan kejadian risiko panen TBS kelapa sawit di setiap rantai pasca panen yang dilalui mulai dari lahan sampai ke TPH di PT. Perkebunan Nusantara III Kebun Batang Toru Afdeling II Sipisang, Kabupaten Tapanuli Selatan, Sumatra Utara. 3) Menganalisis bagaimana dampak dan status risiko serta penanganan panen TBS kelapa sawit di setiap rantai yang dilalui di PT. Perkebunan Nusantara III Kebun Batang Toru Afdeling II Sipisang, Kabupaten Tapanuli Selatan, Sumatra Utara.

\section{Metode Penelitian}

Penelitian ini dilaksanakan selama 2 bulan yang dimulai dari tanggal 27 Februari sampai dengan 27 April 2017 di PT. Perkebunan Nusantara III Kebun Batang Toru Afdeling II Sipisang, Kabupaten Tapanuli Selatan, Provinsi Sumatera Utara. Analisis data yang dilakukan adalah analisis penelitian deskriptif kuantitatif. Penelitian deskriptif merupakan penelitian yang dimaksudkan untuk mengumpulkan informasi mengenai status suatu gejala yang ada, yaitu keadaan gejala menurut apa adanya pada saat penelitian dilakukan [3].

Analisis deskriptif digunakan untuk mengindentifikasi sumber-sumber risiko dan faktor yang mempengaruhi kehilangan hasil pasca panen TBS seperti kematangan buah, TBS restan, Kebersihan piringan dan area lahan, Kehilangan Hasil Produksi di Tempat Pengumpulan Hasil (TPH). Analisis deskriptif dilakukan berdasarkan penilaian objektif yang ada pada aktivitas pemanenan, teknik panen, serta kegiatan pasca panen selanjutnya hingga TBS menuju ke TPH.

1. Tahapan panen TBS kelapa sawit. Panen merupakan salah satu faktor penting yang menentukan kualitas dan kuantitas produksi. Pekerjaan panen meliputi persiapan panen (menghitung angka kerapatan panen), pemotongan tandan TBS, pengutipan brondolan, pengangkutan ke TPH dan pengawasan panen[4].

2. Sumber-sumber risiko kehilangan hasil produksi. Sumber-sumber risiko kehilangan hasil produksi diketahui dengan cara melakukan pengamatan secara langsung dilapangan pada saat kegiatan panen dilakukan. Sumber-sumber risiko yang diamati adalah sumber-sumber yang menyebabkan kehilangan hasil produksi TBS pada saat panen dlakukan hingga TBS sampai di TPH. 
3. Pengukuran kehilangan hasil TBS. Pengukuran kehilangan hasil TBS ini dihitung sesuai dengan alur yang dilewati oleh TBS dari petani hingga ke tempat pengolahan akhir (pabrik). Pengukuran ini akan menggambarkan seberapa besar kehilangan TBS di setiap alur yang dilewatinya dengan menggunakan rumus berdasarkan referensi jurnal ilmiah Nugraha et al. (2007) dalam [2] yaitu besarnya kehilangan ketika pemanenan adalah sebagai berikut:

$\mathrm{KHHP}=\frac{G 1}{G 1 G 2} \times 100 \%$

4. Pengukuran Kemungkinan Terjadinya Risiko. Risiko dapat diukur jika diketahui kemungkinan terjadinya risiko dan besarnya dampak risiko terhadap perusahaan. Ukuran pertama dari risiko adalah besarnya kemungkinan terjadinya yang mengacu pada seberapa besar probabilitas risikoakan terjadi. Metode yang digunakan untuk mengetahui kemungkinan terjadinya risiko adalah metode nilai standar atau z-score. Kountur (2008) dalam [2] langkah yang perlu dilakukan untuk melakukan perhitungan kemungkinan terjadinya risiko menggunakan metode ini dan di aplikasikan pada kehilangan hasil yang terjadi pada TBS kelapa sawit adalah:

a. Menghitung rata-rata kejadian berisiko (kehilangan tandan buah segar)

$$
\chi=\frac{\sum_{\mathrm{i}=1}^{\mathrm{n}} x i}{n}
$$

b.

Menghitung nilai standar deviasi dari kejadian berisiko.

$$
\mathrm{S}=\sqrt{\frac{\sum_{i=1}^{n}(x \bar{i}-x)^{2}}{n-1}}
$$

c. Menghitung z-score

$$
\mathrm{Z}=\frac{x-x}{s}
$$

d. Mencari probabilitas terjadinya risiko produksi Probabilitas diperoleh dari tabel distribusi z. Cari nilai z pada sisi kiri dan bagian atas, pertemuan antara nilai z pada isi tabel merupakan probabilitas. Sehinga dapat diketahui berapa persen kemungkinan terjadinya keadaan dimana produksi TBS mendatangkan kerugian.

e. Analisis Dampak Risiko. Metode yang paling efektif digunakan dalam mengukur dampak risiko adalah $\mathrm{VaR}$ (Value at Risk). VaR adalah kerugian terbesar yang mungkin terjadi dalam rentang waktu tertentu yang diprediksikan dengan tingkat kepercayaan tertentu.

$$
\mathrm{VaR}=\mathrm{x}+\mathrm{z}\left(\frac{s}{\sqrt{\mathrm{n}}}\right)
$$

Ketika selesai pemanenan, biasanya TBS akan diangkut menuju ke tempat berikutnya dan akan dikumpulkan di suatu tempat agar bisa diangkut dengan hasil produksi TBS. Maka dengan kata lain, TBS akan menuju ketempat kedua, dimana TBS akan di angkut dan disimpan dan biasanya TBS tersebut dikumpulkan dan dingkut keesokan harinya.

$$
\text { Wt. Loss }=\frac{W i-W f}{W i} X 100 \%
$$


Setelah mengetahui berapa jumlah kehilangan tiap jalur yang dilalui, maka dilakukan pemetaan sesuai dengan jalur yang dilalui TBS hingga sampai ke pabrik pengolahan kelapa sawit dengan mencantumkan setiap kerugian yang ada dalam bentuk nominal rupiah.

$$
\mathrm{TR}=\mathrm{P} \times \mathrm{Q}
$$

\section{Hasil dan Pembahasan Tahapan Panen}

a) Perhitungan Angka Kerapatan Panen (AKP)

Perhitungan AKP dilakukan oleh asisten afdeling maupun mandor panen yang bertujuan untuk menentukan (dalam bentuk taksiran/ramalan) seberapa banyak jumlah TBS yang akan dipanen, kebutuhan tenaga pemanen, dan truk angkut TBS yang akan digunakan. Pohon sampel yang diamati untuk penentuan AKP adalah pohon sampel yang ada dalam areal panen kelapa sawit.

b) Pemanenan TBS kelapa sawit

Pemanenan TBS kelapa sawit dilakukan oleh karyawan panen kelapa sawit PTPN III Kebun Batang Toru Afdeling II Sipisang dengan menggunakan egrek. Sebelum dilakukan kegiatan panen, mandor terlebih dahulu membagi areal panen kepada setiap pemanen, selanjutnya pemanen mencari buah matang sesuai sesuai kriteria panen.

c) Pengangkutan TBS ke TPH

TBS dan brondolan yang telah di panen selanjutnya diangkut menuju TPH menggunakan angkong (gerobak). Sebelum TBS diangkut menuju TPH, terlebih dahulu TBS diberi nomor kode pemanen dan tanggal panen di tangkai TBS.

d) Pemeriksaan panen kelapa sawit (Kap Inspeksi)

Pemeriksaan panen (kap inspeksi) di PTPN III Kebun Batang Toru Afdeling II Sipisang dilaksanakan oleh asisten afdeling, mandor I, petugas kap inspeksi afdeling dan mandor panen terhadap areal yang dipanen pada hari panen dan produksi di TPH. Tujuan dari kegiatan kap inspeksi adalah untuk mempertahankan dan meningkatkan disiplin pelaksanaan panen sesuai norma serta penentuan kelas bagi pemanen.

e) Pengangkutan TBS ke pabrik kelapa sawit (PKS)

Untuk menjamin bahwa semua produksi TBS dari areal panen kelapa sawit yang dipanen diangkut ke pabrik kelapa sawit, maka tahapan yang dilakukan untuk proses pengangkutan TBS ke pabrik dengan merencanakan dengan matang kebutuhan truck untuk pengangkutan TBS ke pabrik.

f) Penimbangan dan sortasi TBS di PKS

TBS yang dibawa ke pabrik akan diseleksi di tempat sortasi dan kemudian ditimbang. Hasil penimbangan dan sortasi TBS di PKS dikeluarkan kwitansi yang diberikan ke pihak afdeling dan petugas pengangkutan TBS sebagai pedoman produksi yang didapatkan per hari panen.

\section{Sumber-sumber Risiko Kehilangan Hasil Produksi}

a. Kehilangan Hasil Produksi di Lahan

Tanaman kelapa sawit di PTPN III Kebun Batang Toru Afdeling II Sipisang sudah berumur 16/17 tahun sehingga alat untuk memanen buah berupa egrek (alat panen berbentuk parang sabit dengan tangkai yang panjang) yang tinggi tangkainya disesuaikan dengan tinggi tanaman. Sistem panen yang ditetapkan di PTPN III Kebun Batang Toru Afdeling II Sipisang adalah 5/7 dan 6/7. Sistem panen 5/7 (lima hari panen dalam seminggu) diterapkan pada semester I dalam tahun panen (Januari sampai Juni). Sistem panen 6/7 (enam hari panen dalam seminggu) diterapkan pada semester II dalam tahun panen (Juli sampai Desember).

1. Kematangan Buah.

Secara umum tanda yang digunakan untuk mencirikan buah layak panen adalah adanya brondolan luar yang telah lepas dari tandan dan jatuh secara alami di piringan pohon. Apabila dipiringan pohon di jumpai brondolan 1 butir/kg TBS jatuh secara alami, maka buah tersebut telah layak panen dengan kata lain telah memenuhi kriteria matang panen.

2. TBS Restan (tidak diangkut pada hari panen).

TBS restan adalah produksi TBS yang dihasilkan tidak terangkut pada saat dilakukan proses pemanenan. TBS restan dikarenakan kurangnya Truck untuk mengangkut hasil 
produksi TBS ke PKS sehingga TBS yang telah selesai dipanen harus tinggal dilahan ataupun TPH kemudian diangkut kembali pada hari berikutnya.

3. Kebersihan piringan dan area lahan

Kebersihan piringan ditandai dengan tidak adanya gulma yang tumbuh di sekitar piringan mapun disekitar area lahan tanaman kelapa sawit. Tanaman gulma yang sering dijumpai menyerang tanaman kelapa sawit adalah gulma rumput-rumputan dan gulma anak kayu.

4. Kehilangan Hasil Produksi di Tempat Pengumpulan Hasil (TPH)

Setelah kegiatan panen TBS selesai dilakukan, karyawan panen akan membawa TBS yang sudah diturunkan dari pohon dengan menggunakan angkong atau sorongan menuju ke TPH dan disusun di area TPH agar mempermudah dalam perhitungan buah.

\section{Kehilangan Hasil Produksi TBS}

Tabel 1. Persentase Kehilangan Hasil Pasca Panen Kelapa Sawit di PTPN III Kebun Batang Toru Afdeling II Sipisang.

\begin{tabular}{clc}
\hline No & \multicolumn{1}{c}{ Tempat Kehilangan (Post - Lossses) } & \% Kehilangan Hasil Produksi (Losses) \\
\hline 1 & Losses brondolan di lahan & $7.05 \%$ \\
2 & Losses brondolan di TPH & \\
3 & Losses brondolanRestan & \\
\hline
\end{tabular}

\section{Analisis Kemungkinan Terjadinya (Probabilitas) Loss post-harvest TBS}

Kegiatan pasca panen perkebunan kelapa sawit di PTPN III Kebun Batang Toru Afdeling II Sipisang terdapat suatu risiko dimana dapat mengakibatkan kurang maksimalnya hasil produksi TBS yang dihasilkan. Hal tersebut diakibatkan karena hasil panen TBS yang dihasilkan menyusut (hilang) mulai dari TBS dipanen (dilahan) sampai TBS diangkut ke pabrik untuk diolah losses hasil TBS ditiap pos yang dilalui akan mengurangi produksi yang seharusnya didapat oleh pihak PTPN III Kebun Batang Toru Afdeling II Sipisang sebelum dikirim ke PKS. Data yang digunakan dalam menghitung probabilitas losses yang terjadi di lahan adalah produksi bersih TBS yang telah dikurangi losses yang terjadi di lahan sampai di TPH pada bulan Maret tahun 2017. Setelah itu dilanjutkan dengan menghitung nilai z-score losses di bagian lahan sampa di TPH pada proses pasca panen kelapa sawit.

Berdasarkan analisis yang dilakukan, kemungkinan terjadinya loss (kehilangan) hasil produksi dibagian lahan sampai TPH adalah sebesar 4,4\%. Hasil perhitungan tersebut didapat dari perhitungan nilai standar dengan hasil nilai z-score nya sebesar -1,70. Dapat dilihat pada tabel 2.

Tabel 2. Analisis Perhitungan Probabilitaslosses di Bagian Lahan - TPH Bulan Maret 2017.

\begin{tabular}{ccccr}
\hline Tanggal & $\begin{array}{c}\text { Produksi yang } \\
\text { dipanen }(\mathrm{Kg})\end{array}$ & $\begin{array}{c}\text { Losses Brondolan } \\
(\mathrm{Kg})\end{array}$ & $\begin{array}{c}\text { Produksi TBS } \\
\text { yang dikirim }(\mathrm{Kg})\end{array}$ & $\begin{array}{c}\text { Restan } \\
(\mathrm{Kg})\end{array}$ \\
\hline 27 & - & - & - & 7.980 \\
28 & 13.223 & 1.058 & 12.165 & 3.084 \\
1 & 16.929 & 1.341 & 15.588 & 8.347 \\
2 & 15.575 & 1.246 & 14.329 & 25.168 \\
3 & 13.030 & 1.040 & 11.990 & 33.708 \\
4 & - & - & - & 11.576 \\
5 & - & - & - & 4.626 \\
6 & 18.284 & 1.476 & 16.808 & 7.769 \\
7 & 20.891 & 1.669 & 19.222 & 30.329 \\
8 & 19.416 & 1.764 & 17.652 & 25.082 \\
9 & - & - & - & 6.612 \\
13 & 25.157 & 1.783 & 23.374 & - \\
14 & 27.779 & 1.941 & 25.838 & - \\
15 & 28.886 & 2.024 & 26.862 & - \\
20 & 22.120 & 1.480 & 20.640 & - \\
21 & 24.740 & 1.810 & 22.930 & - \\
22 & 24.565 & 1.995 & 22.570 & -
\end{tabular}




\begin{tabular}{|c|c|c|c|c|}
\hline 27 & 20.601 & 1.449 & 19.152 & - \\
\hline 29 & 29.773 & 2.097 & 27.676 & - \\
\hline 30 & 26.842 & 2.128 & 24.714 & - \\
\hline 31 & 3.740 & 400 & 3.340 & - \\
\hline Total & 351.551 & 26.701 & 324.850 & 178.985 \\
\hline Rata-rata (x) & & & $19.108,82$ & \\
\hline Standar deviasi & & & 6361,74 & \\
\hline $\mathrm{X}$ & & & 1.200 & \\
\hline $\mathrm{Z}$ & & & $-1,70259$ & \\
\hline Nilai pada tabel Z & & & 0.044 & \\
\hline Probabilitas & & & 4,4 & \\
\hline
\end{tabular}

Berdasarkan analisis yang dilakukan pada penggunaan selang kepercayaan 95 persen atau nilai pada distribusi tabel z pada tingkat 5 persen menunjukkan kerugian Value at Risk (VaR) pada kejadian risiko di bagian lahan sebesar Rp 2.209.160,53. Dapat dilihat pada tabel 3.

Analisis Dampak Loss post-harvest TBS

Tabel 3. Analisis Dampak Kehilangan Hasil Produksi TBS dari Lahan Sampai TPH Bulan Maret 2017

\begin{tabular}{|c|c|c|}
\hline \multirow{2}{*}{ Tanggal } & Losses (kg) & Kerugian (Rp) \\
\hline & Lahan - TPH & Lahan - TPH \\
\hline 28 & 1.058 & 1.333 .080 \\
\hline 1 & 1.341 & 1.689 .660 \\
\hline 2 & 1.246 & 1.569 .960 \\
\hline 3 & 1.040 & 1.310 .400 \\
\hline 6 & 1.476 & 1.859 .760 \\
\hline 7 & 1.669 & 2.102 .940 \\
\hline 8 & 1.764 & 2.222 .640 \\
\hline 13 & 1.783 & 2.246 .580 \\
\hline 14 & 1.941 & 2.445 .660 \\
\hline 15 & 2.024 & 2.550 .240 \\
\hline 20 & 1.480 & 1.864 .800 \\
\hline 21 & 1.810 & 2.280 .600 \\
\hline 22 & 1.995 & 2.513 .700 \\
\hline 27 & 1.449 & 1.825 .740 \\
\hline 29 & 2.097 & 2.638 .440 \\
\hline 30 & 2.128 & 2.681 .280 \\
\hline 31 & 400 & 504.000 \\
\hline Total & & 33.639 .480 \\
\hline Rata-rata & & $1.978 .729,94$ \\
\hline Standar Deviasi & & 577547.34 \\
\hline $\mathrm{Z}(5 \%)$ & & 1,645 \\
\hline VaR (Rp) & & $2.209 .160,53$ \\
\hline
\end{tabular}

\section{Pemetaan Loss post-harvest TBS}

Tabel 4. Status Risiko Pada Kehilangan Hasil Produksi Kelapa Sawit.

\begin{tabular}{clc}
\hline No & \multicolumn{1}{c}{ Tempat Kehilangan (Post - Lossses) } & Nilai Status Resiko (Rp) \\
\hline 1 & Losses brondolan di lahan & \\
2 & Losses brondolan di TPH & $8.836 .642,12$ \\
3 & Losses brondolanRestan & \\
\hline
\end{tabular}

Penentuan besar atau kecilnya probabilitas adalah berdasarkan tingkat persentase terjadinya kehilangan hasil produksiTBS di PT. Perkebunan Nusantara III Kebun Batang Toru Afdeling II Sipisang dan batas antara probabilitas besar dan kecil adalah sebesar 5 persen. Dengan mengetahui tingkat probabilitas dan dampak dari loss hasil produksi di lahan sampai TPH, maka dapat diklarifikasikan ke dalam empat kuadran risiko berdasarkan tingkat kemungkinan terjadinya dan dampak yang ditimbulkan dari losses di lahan sampai TPH. 
Probabilitas (\%)

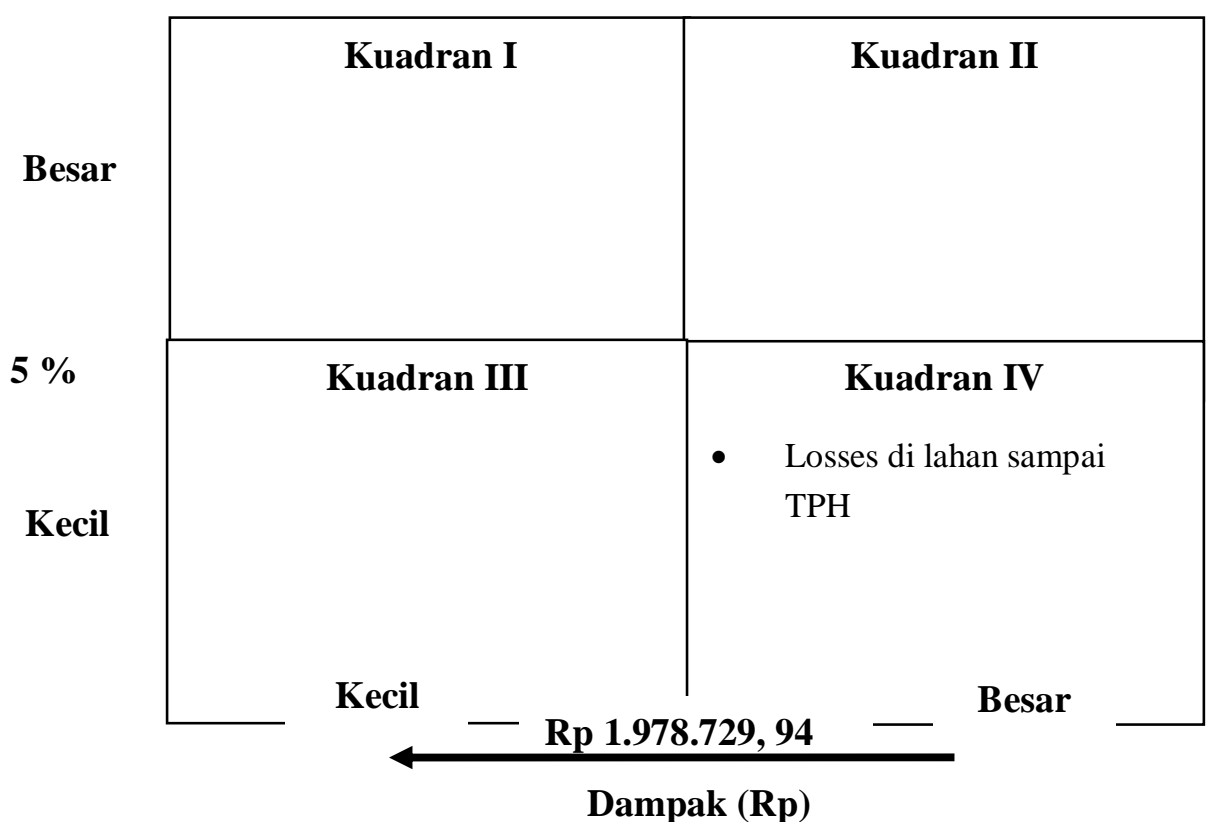

Gambar 1. Peta Hasil Identifikasi Kehilangan Hasil Produksi TBS Kelapa Sawit

Dari hasil pemetaan risiko yang telah dilakukan, dapat dilihat posisi lossesyang terdapat pada rantai pasca panen TBS di PT. Perkebunan Nusantara III Kebun Batang Toru Afdeling II Sipisang. Kehilangan hasil produksi TBS di lahan sampai TPH terletak pada kuadran IV dimana tingkat probabilitas yang dapat muncul dari hilangnya hasil produksi TBS sebesar 4,4 persen dengan dampak kerugian yang dihasilkan adalah sebesar Rp 2.209.160,53. Tahap akhir dari analisiskehilangan produksi TBS kelapa sawit di PT. Perkebunan Nusantara III Kebun Batang Toru Afdeling II Sipisang yaitu strategi penanganan yang baik terhadap losseshasil produksi di lahan sampai TPH. Strategi penanganan ini sangat erat kaitannya dengan pemetaan besarnya losseshasil produksi yang telah dihasilkan.

Probabilitas (\%)

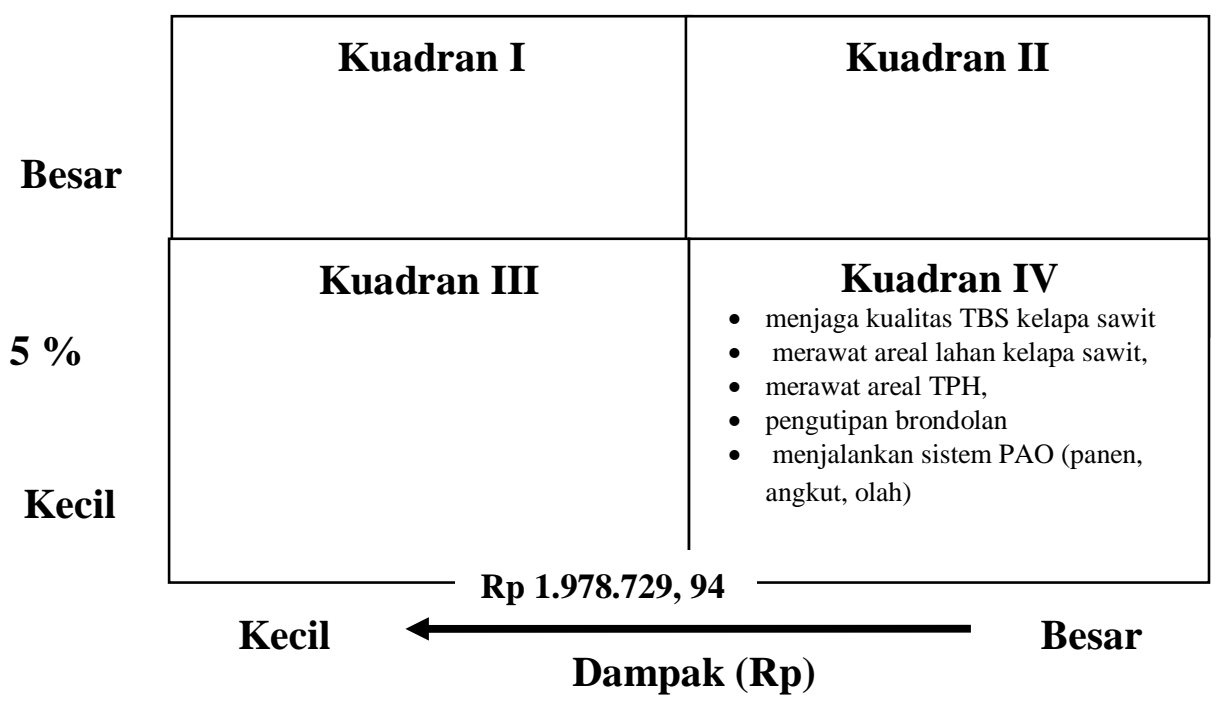

Gambar 2. Strategi Penanganan Mitigasi Kehilangan Hasil ProduksiTBS Kelapa Sawit 
Berdasarkan hasil analisis status risiko dan besar probabilitas maupun dampak yang ditimbulkan dari Loss post-harvestTBS kelapa sawit di PT. Perkebunan Nusantara III Kebun Batang Toru Afdeling II Sipisang dapat diurutkan strategi yang dilakukan dalam menangani Loss postharvest TBS kelapa sawit di PT. Perkebunan Nusantara III Kebun Batang Toru Afdeling II Sipisang. Adapun strategi yang pertama dalam menangani loss post-harvest adalah di bagian lahan sampai TPH menjaga kualitas panen TBS, merawat areal lahan, merawat areal TPH, pengutipan brondolan dan menjalankan sistem PAO (panen, angkut, olah).

\section{Kesimpulan}

Sumber-sumber kehilangan hasil produksi (loss post-harvest) TBS kelapa Sawit di PT. Perkebunan Nusantara III Kebun Batang Toru Afdeling II Sipisang adalah kematangan buah, TBS restan (tidak diangkut pada hari panen) dan kebersihan piringan dan area lahan. Jumlah persentasi kehilangan hasil produksi (loss postharvest) TBS adalah sebesar 7, $05 \%$ dari seluruh total rata-rata TBS yang dihasilkan. Losses tersebut berada di bagian lahan sampai TPH, di PT. Perkebunan Nusantara III Kebun Batang Toru Afdeling II Sipisang. Dampak kerugian kehilangan hasil produksi (loss post-harvest) TBS kelapa sawit di PT. Perkebunan Nusantara III Kebun Batang Toru Afdeling II Sipisang di bagian lahan sampai TPH secara total pada bulan maret 2017 adalah sebesar Rp 2.209.160,53 dengan persentase kemungkinan kejadian (probabilitas) sebesar 4,4 persen. Hasil kerugian yang ditimbulkan oleh loss post-harvest TBS di PT. Perkebunan Nusantara III Kebun Batang Toru Afdeling II Sipisang terbilang cukup kecil perbulannya karena pengaruh kegiatan pasca panen yang relatif lebih singkat. Strategi penanganan mitigasi yaitu berupa menjaga kualitas panen TBS kelapa sawit, merawat areal lahan kelapa sawit, merawat areal TPH, pengutipan brondolan yang tetinggal dan menjalankan sistem PAO (panen, angkut, olah).

\section{Daftar Pustaka}

[1] Pardamean, M. 2012. Sukses Membuka Kebun dan Pabrik Kelapa Sawit. Penebar Swadaya. Jakarta. 236 Hal.

[2] Samosir, N.H. 2013. Analisis Risiko Pasca Panen Tandan Buah Segar (TBS) Kelapa Sawit (Kasus : Desa Tanah Datar Kecamatan Kunto Darussalam Kabupaten Rokan Hulu Provinsi Riau). Institut Pertanian Bogor (IPB).

[3] Arikunto, S. 2009. Manajemen Penelitian. Rineka Cipta. Jakarta. 504 Hal.

[4] Sunarko. 2009. Budi Daya dan Pengelolaan Kebun Kelapa Sawit dengan Sistem Kemitraan. Agromedia Pustaka. Jakarta. 178 Hal. 